\section{Multiple Subcutaneous Gouty Tophi Even with Appropriate Medical Treatment: Case Report and Review of Literature}

Troy D. Erickson, D.O., FAAOS1, Binara Assylbekova, M.D. ${ }^{2}$, Alexander C.M. Chong, MSAE, MSME ${ }^{3,4}$

${ }^{1}$ Sanford Thief River Falls Clinic, Thief River Falls, MN ${ }^{2}$ Sanford Broadway Medical Center, Fargo, ND

${ }^{3}$ Sanford Health Department of Graduate Medical Education, Fargo, ND

${ }^{4}$ University of North Dakota, School of Medicine \& Health Sciences, Grand Forks, ND

Received July 28, 2020; Accepted for publication Sept. 23, 2020; Published online Jan. 21, 2021 https: doi.org 10.17161 lijm.voll414505

\section{INTRODUCTION}

Gout is one of the most common and complex causes of arthritis that can affect anyone., ${ }^{1,2}$ It is one of the most ancient medical conditions known going back to references in Egypt in 2640 BC and Hippocrates writing about it in $400 \mathrm{BC} .^{3-5}$ Gout occurs when there are deposits of urate monosodium crystals in the synovial fluid and other tissues causing the inflammation and intense pain of a gout attack. Urate monosodium crystals usually are associated with longterm hyperuricemia that is triggered by several genetic factors as well as environmental factors such as the overconsumption of rich purine diets, alcohol, obesity, obesity-related disease, kidney disease, and certain medications. ${ }^{1,6-13}$ Risk factors for older patients include lowdose aspirin, alcohol abuse, decreased renal function, and prolonged use of diuretics. ${ }^{14,15}$

Advanced gout, also known as gouty tophi, are large, visible (masses) made up of urate crystals., ${ }^{5,16,17}$ The tophus is a cardinal sign and usually develops after 5-10 years of chronic undertreated gout with the olecranon bursa being one of the most affected areas. ${ }^{5,16,17}$ Formation is caused by elevated serum uric acid levels due to neglected and poorly controlled gout. ${ }^{18,19}$

Gouty tophi can develop anywhere. It can develop in periarticular soft tissues, sub-articular regions around bones, tendon sheaths, bursas, articular cartilage, and synovial tissues around flexor tendons. ${ }^{17,20}$ Gouty tophi have been identified in vocal cords, myocardium, heart valves, eyes, spinal cord, pancreatic tail, breast, penis, with a propensity to affect the helix of the ear. ${ }^{17,21,22}$ However, patients with multiple gouty tophi rarely are encountered because hyperuricemia can be treated effectively. The differential diagnosis of gouty tophi is broad, even though gout can be diagnosed clinically by elevated serum uric acid level; however, the concentration of serum uric acid may be within the normal limits and yet gouty tophi still can be developed. ${ }^{23-25}$

This case was a patient who developed multiple gouty tophi over an extended period of time with increasing size of the masses while on medical treatment for his gout. The one mass of unique interest developed over the superficial anterior tibia just distal to the tibial tubercle and not in the patellar tendon, which is uncommon.

\section{CASE REPORT}

A 65-year-old obese male (height: $177.8 \mathrm{~cm}$; weight: $123.3 \mathrm{~kg}$; BMI: $39.0 \mathrm{~kg} / \mathrm{m}^{2}$ ) had advanced cardiac disease, and atrial fibrillation. He

\section{KANSAS JOURNAL of MEDICINE}

was on anticoagulation and presented to his primary care physician with intermittent pain and a mass on the left olecranon region of greater than 20 years. He was a non-smoker and drank no alcohol. His serum uric acid level was $8.3 \mathrm{mg} / \mathrm{dL}$.

The patient was referred to an orthopedic clinic due to the mass. Physical examination revealed a prominent soft tissue mass that measured $30 \mathrm{~cm} \times 12 \mathrm{~cm} \times 4 \mathrm{~cm}$, with a small laceration over the left dorsal proximal forearm, distal to the olecranon. The patient had no pain with active range of motion, but the lesion was painful with direct pressure over the subcutaneous mass. He complained of a soft tissue growth on his left elbow/forearm that had been enlarging slowly over the previous 2 - 3 years. He previously had undergone nonsurgical treatment that included needle aspiration of fluid from the soft tissue growth about 10 years previously with no significant relief of the symptoms, at that time the patient was diagnosed with an olecranon bursa. No record of the fluid being sent for microbiological exam was noted. He denied recent trauma to the area but a small laceration was noted. He was not on any medications for gout but was on many medications for his heart disease and hypertension to include loop diuretics and anticoagulants.

Plain radiographs (Figure 1) of the left elbow showed mild spur formation with a soft tissue mass. Computed tomography (CT) revealed a cystic accumulation with some calcific heterogenicity around the margins of the cystic tissue. CT was performed instead of using magnetic resonance imaging (MRI) because the patient had a pacemaker that prevented him from having a scan. From the radiographic images, he was diagnosed with an olecranon bursitis on his left elbow.

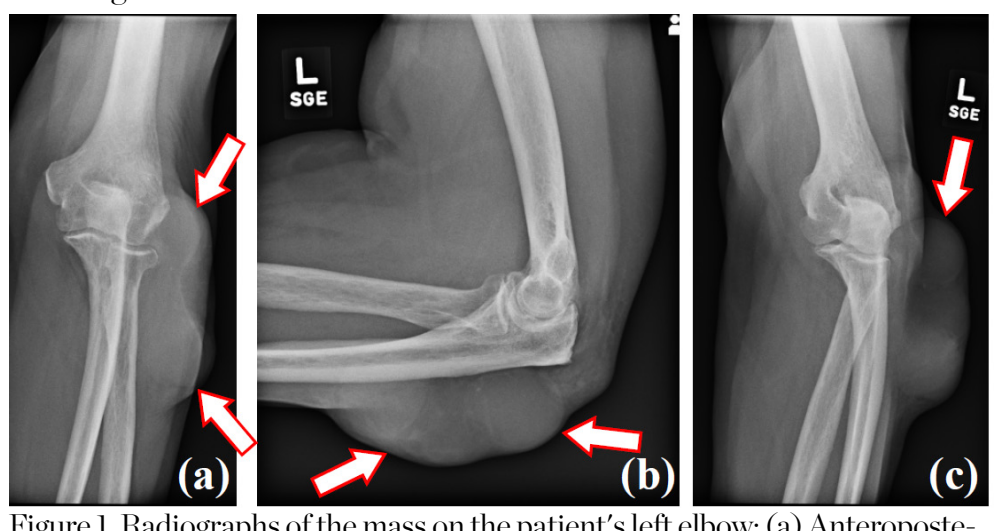

Figure 1. Radiographs of the mass on the patient's left elbow: (a) Anteroposterior view, (b) Lateral view, (c) Oblique view.

Surgical resection of the mass was performed due to the pain when the patient would lean on it and the fact that there was a small laceration distal to the mass that would not heal. Operative report showed the mass was superficial to the fascia and periosteum with the size measured at $15 \mathrm{~cm} \times 7 \mathrm{~cm} \times 4.5 \mathrm{~cm}$. It was fixed in formalin and the histopathology (Figure 2) revealed a gouty tophus with the presence of morphologic features and polarization characteristics (inflammation, fibrosis, and hemorrhage associated with abundant crystalline material). 


\section{KANSAS JOURNAL of MEDICINE} SUBCUTANEOUS GOUTYTOPHI continued.

Post-operatively, the patient developed a complex wound infection (skin loss and necrosis of the wound) ultimately undergoing multiple irrigations, debridements, and skin grafting procedures. With the patient's multiple medical comorbidities including the need for anticoagulants, wound healing was prolonged. Four-months postoperatively, the patient's elbow showed no evidence of infection; the wound appeared clean and had healed. The patient had almost full range of motion at the time. His serum uric acid level was $6.9 \mathrm{mg} / \mathrm{dL}$ while being treated with allopurinol.

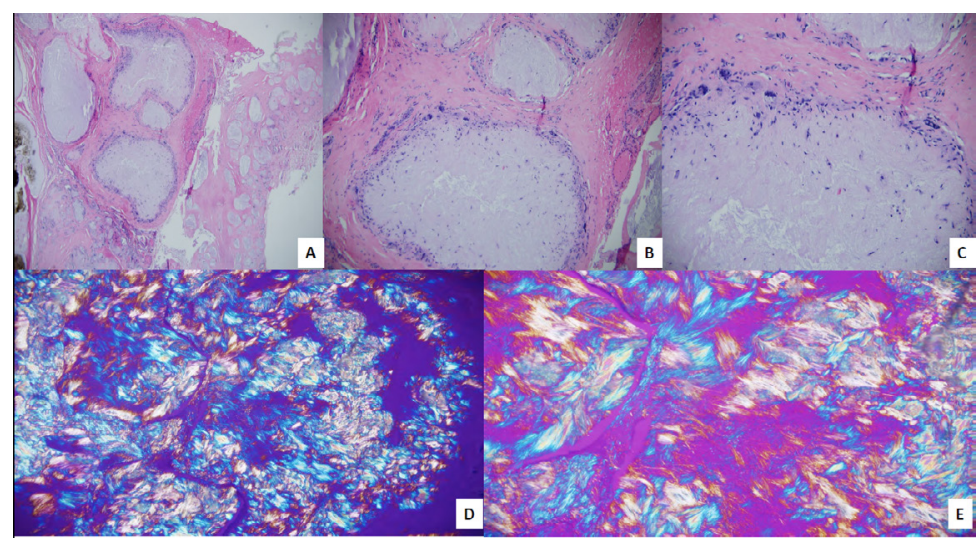

Figure 2. The histological examination of the mass on the left elbow. (A, B, C) Magnification view of eosinophilic amorphous material surrounded by histiocytic and chronic inflammation (x4, xl0, and x20 power view). (D, E) Magnification view under polarizer showing needle shaped negatively birefringent crystals (10x and 20x power view).

Two and half years after the left elbow surgeries, the patient presented to the orthopedic clinic with two large soft tissue masses. One about the anterior aspect of the left tibia at approximately the junction of the proximal and mid-third of the tibia, and another one on the posterior aspect of the right elbow that had developed since his previous surgeries. The patient had no significant pain at either location unless he leaned on either of the two areas. Exam of the left knee showed a soft tissue mass that measured approximately $6 \mathrm{~cm} \times 6 \mathrm{~cm}$ over the front of the left tibia, medial and distal to the patellar tendon and tibial tubercle, and the right elbow soft tissue mass measuring about $8 \mathrm{~cm}$ across with no redness or breakdown of the skin.

Plain radiographs of the right elbow showed a large soft tissue mass (Figures 3A - 3C). The left knee plain radiographs revealed medial compartmental narrowing and a large soft tissue prominence over the proximal tibia (Figures 3D - 3E).

The patient's health history had worsened, and it was significant for congestive heart failure, diabetes, atrial fibrillation, pacemaker/ defibrillator, previous myocardial infarction, hypertension, chronic warfarin and clopidogrel use, hyperlipidemia, sleep apnea, varicosities, and gout. Due to his multiple co-morbidities and previous complications with surgery, the patient elected for non-surgical treatment even after discussion with the orthopedic surgeon who recommended excision of the masses before they broke down.
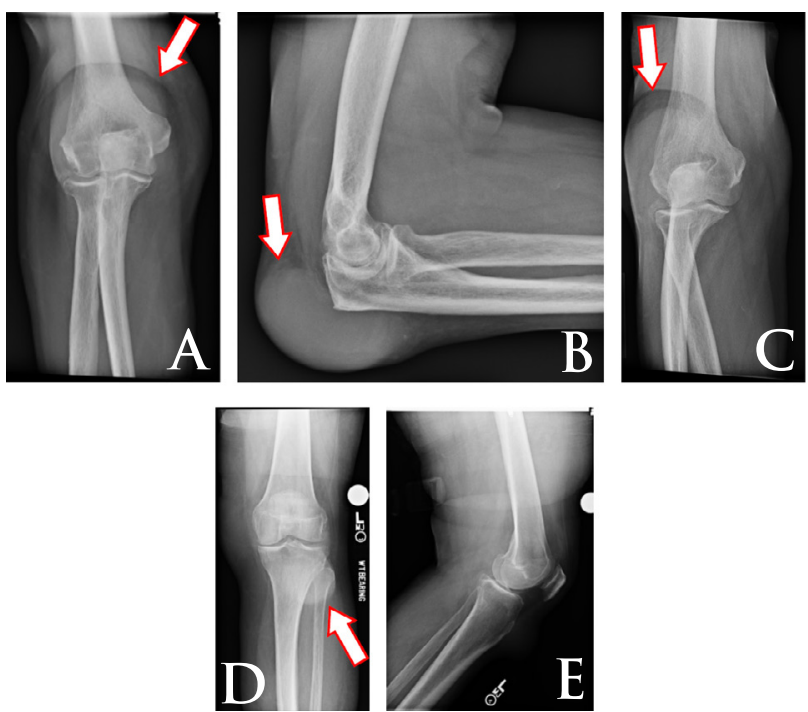

Figure 3. Radiographs of the mass on the patient. (A, B, C) right elbow and (D, E) left knee.

The patient accidentally bumped the mass over his anterior left tibia approximately 12 months after his last orthopedic office visit. His primary care provider had been trying to treat this conservatively without success. Due to the patient being on warfarin and clopidogrel, the mass had been oozing and bleeding since that time, wound care was not working, and the mass continued to drain. Approximately 2.5 months later, the patient presented to another orthopedic surgeon with a large bleeding mass over the anterior left tibia. His serum uric acid level was $4.2 \mathrm{mg} / \mathrm{dL}$ which was below the defined serum urate level for hyperuricemia $(>6.8 \mathrm{mg} / \mathrm{dL}){ }^{26-28}$ Physical exam revealed a large skin lesion on the left anterior tibial region of the knee that had a black eschar formation that would bleed intermittently (Figure 4). Plain radiographs showed moderate osteoarthritis involving the medial compartment with meniscal calcifications and a soft tissue mass about the anterior tibial region (Figure 5). Discussion with the patient centered on mass excision with irrigation and debridement due to concern for infection and the fact that it had not healed with 2.5 months of conservative treatment.
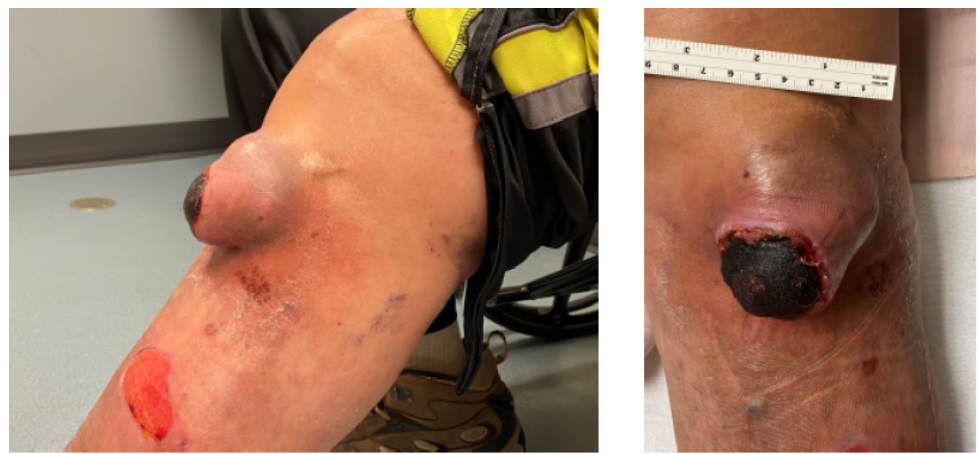

Figure 4. Lateral and anterior views of the left tibial mass.
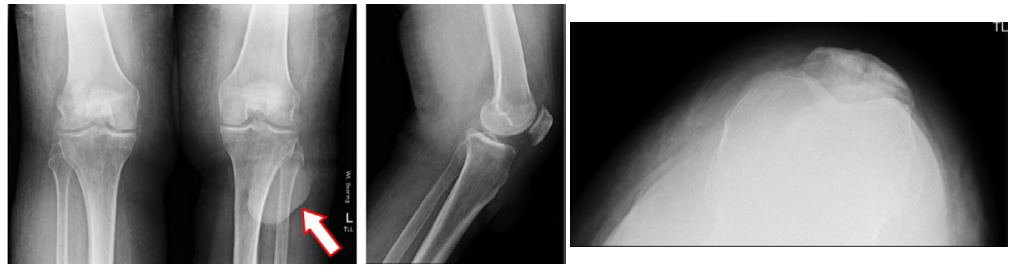

Figure 5. Radiographs of the mass on the patient's left knee. 
Surgical resection of the mass was performed. Due to the extended timeline to seek orthopedic care, the mass had compromised the skin leading to poor tissue for coverage. The mass was superficial, extending along the anterior-medial aspect of the proximal tibia just distal to the tibial tubercle. It measured $7 \mathrm{~cm} \mathrm{x} 7 \mathrm{~cm} \times 5 \mathrm{~cm}$ (Figure 6). The mass was sent in saline, and the histopathology revealed a gouty tophus with associated and marked necrosis, hematoma and suppurative inflammation, and no growth of organisms (Figure 7).

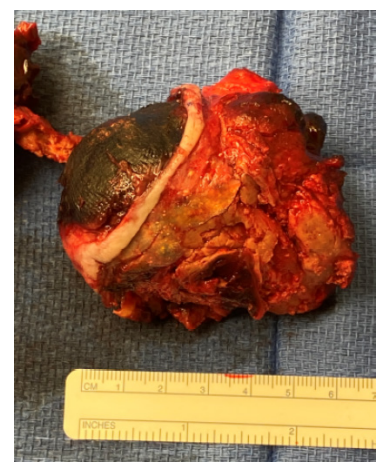

Figure 6. Resected mass from the left knee.

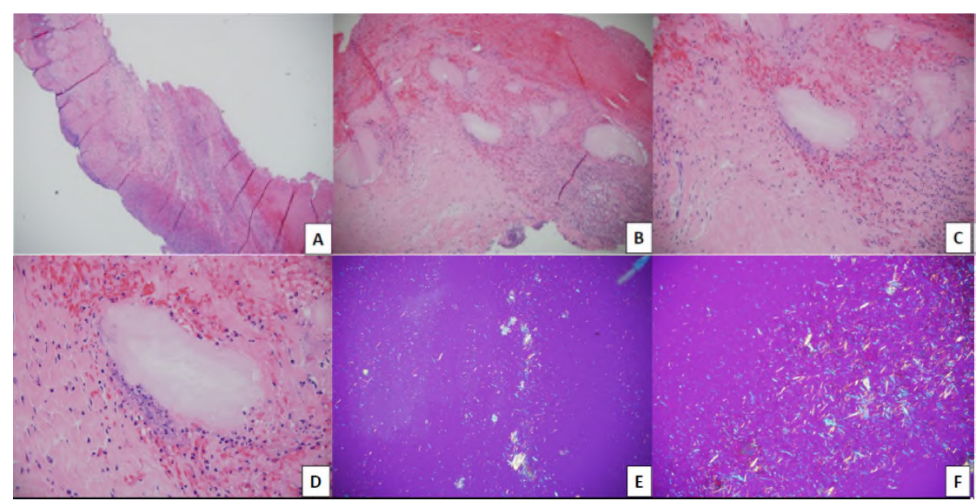

Figure 7. The histological examination of the mass on the left knee. (A) Proximal anterior tibia mass specimen showing surface skin ulceration. (B, C, D) Acutely and chronically inflamed fibrous tissue with nodular accumulation of amorphous pale pink material (x2, $\mathrm{x} 4$ and $\mathrm{xl0}$ power views). (E, F) Touch preparations from fresh tissue show needle shaped negatively birefringent crystals.

The patient had difficulties healing the incision site and underwent wound care with a wound vac, and other modalities with no further operative intervention. Three months post-operatively, the patient's wound showed no evidence of infection and the wound appeared clean with abundant healing granulation tissue (Figure 8). Due to the patient's poor health conditions, his right elbow mass excision surgery has not been completed.
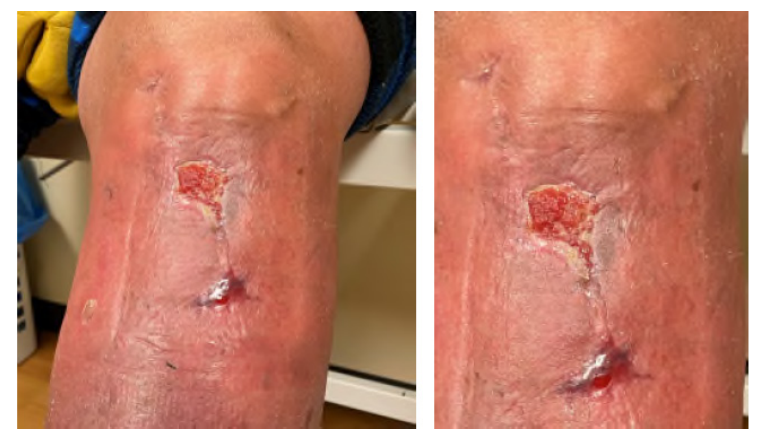

Figure 8. Three months follow up on the left knee.
KANSAS JOURNAL of MEDICINE SUBCUTANEOUS GOUTY TOPHI

continued.

\section{DISCUSSION}

The clinical course of this case provided two interesting findings. The first finding was the symptomatic gouty tophi appeared as a superficial mass along the anterior tibia which is not common. The second finding was that the patient developed multiple gouty tophi over multiple extremities over a couple of years even with appropriate medical treatment to lower his uric acid levels.

It is rare to have gouty tophi formation since hyperuricemia can be treated effectively and the patient was on allopurinol that had lowered his uric acid levels. Hyperuricemia is defined as a serum urate level of approximately $6.8 \mathrm{mg} / \mathrm{dL}$ or higher. ${ }^{26-28} \mathrm{In}$ this case, the patient's uric acid levels dropped to $4.2 \mathrm{mg} / \mathrm{dL}$ which is below the defined level. Even with the medical treatment, the tophi continued to grow in size. This may have been related to his other comorbidities and medications that he was on which included loop diuretics. Loop diuretics (furosemide and bumetanide), thiazide diuretics (chlorthalidone and indapamide), and cyclosporine increase the risk of gout. ${ }^{29-32}$ Of note, serum uric acid levels in chronic tophaceous gout may not be conclusive of hyperuricemia in patients with diabetes. Therefore, his uric levels may have been falsely lower than noted leading the physician to believe that they were normal or at lower levels than they truly were. ${ }^{33}$ The patient also had changed his diet in hopes of modifying his risks for gout recurrence following his providers' recommendations.

Surgical intervention of gouty tophi rarely is needed due to medical management. Surgery is indicated if the tophi are painful, shows impending skin necrosis, infection, ulcerating wound, tendon impairment, mechanical impairment, nerve compression, and joint destruction. ${ }^{34-36}$ Surgery can be challenging because of wound complications. ${ }^{37,38}$ Ochoa et al. ${ }^{39}$ suggested that inflammatory changes of the lobular subcutaneous tissue can be triggered and perpetuated by the arterial blood supply disruption caused by the monosodium urate crystals thus rending tissue vulnerable to deposits. They also believed that some microtrauma of the walls of terminal blood vessels as well as communication loss between the vessels and the dermis occurred, making the tissue vulnerable.

Gouty tophi may appear at intra- or extra-articular locations. ${ }^{40-45}$ It can be in the subcutaneous tissue. It mostly affects peripheral joints, but can involve the extensor tendons of the knee. Bone erosions at the sites of tophi formation are common, but superficial gouty tophi appearing along the anterior tibia is rare when it does not extend from the interarticular knee joint or from the tendon. Usually, these gouty tophi do not cause the patient any pain unless they become acutely inflamed, but they can cause problems when trying to kneel on them.

What is the reason for the higher complication rates? Is it related to waiting too long and having to deal with the aftermath of an open wound and poor skin coverage? Would it be better to remove the tophi earlier in the disease process when they have not eroded through the skin? Gouty tophi and its pathophysiology potentially can lead to the poor healing but waiting until the mass is so large is another problem. 
KANSAS JOURNAL of MEDICINE

SUBCUTANEOUS GOUTYTOPHI

continued.

Skin under tension and thinned out due to the size is a problem no matter the etiology of the mass.

On a final note, it is important to consider how the pathological specimen is sent to the pathologist. The correct fixative is important and the specimens should be submitted in alcohol fixative because the monosodium urate crystals in gout dissolve away in formalin and are lost from hematoxylin and eosin (H\&E) stained sections. ${ }^{46,47}$ Physicians also should consider having cultures done on the specimen as well as a crystal analysis.

\section{CONCLUSION}

This report represented a unique case of how gouty tophi can develop at multiple joint locations over a short time period even with appropriate medical treatment, and how one of these tophi developed in the superficial tissues of the anterior tibia outside of any joint or tendon. Although gouty tophi are not life threatening, it has a significant impact on the quality of life. Intervening sooner medically may be a benefit for the patient with the hope that patient compliance with therapeutics may have an important impact on prognosis and avert surgical intervention. Nevertheless, lab values may misrepresent true uric acid levels. Gouty tophi may need to be removed sooner if therapeutics have not changed the progression and earlier involvement with the surgeon is warranted.

\section{ACKNOWLEDGEMENTS}

Verbal consent was obtained from the patient granting permission that data concerning his case could be submitted for publication. Institutional Review Board approval was unnecessary based on institutional criteria. The authors acknowledge Dr. Benjamin Noonan for his revision and critical comments on the paper.

\section{REFERENCES}

${ }^{1}$ Roddy E, Doherty M. Epidemiology of gout. Arthritis Res Ther 2010; 12(6):223. PMID: 21205285.

${ }^{2}$ Lawrence RC, Felson DT, Helmick CG, et al. Estimates of the prevalence of arthritis and other rheumatic conditions in the United States. Part II. Arthritis Rheum 2008; 58(1):26-35. PMID: 18163497.

${ }^{3}$ Schwartz SA. Disease of distinction. Explore (NY) 2006; 2(6):515-519.

PMID: 17113492.

${ }^{4}$ Hippocrates. The Genuine Works of Hippocrates. Vol. 1. Adams F (Ed). New York: Wood, I and II; 1886

5 Fernandes EA, Lopes MG, Mitraud SA, Ferrari AJ, Fernandes AR. Ultrasound characteristics of gouty tophi in the olecranon bursa and evaluation of their reproducibility. Eur J Radiol 2012;81(2):317-323. PMID: 21237599

${ }^{6}$ Sebesta I. Genetic disorders resulting in hyper- or hypouricemia. Adv Chronic Kidney Dis 2012; 19(6):398-403. PMID: 23089275.

7 Matsuzawa Y. Adiponectin: a key player in obesity related disorders. Curr Pharm Des 2010; 16(17):1896-1901. PMID: 20370675.

${ }^{8}$ Huang HY, Appel LJ, Choi MJ, et al. The effects of vitamin C supplementation on serum concentrations of uric acid: Results of a randomized con trolled trial. Arthritis Rheum 2005; 52(6):1843-1847. PMID: 15934094.

9 Oda M, Satta Y, Takenaka O, Takahata N. Loss of urate oxidase activity in hominoids and its evolutionary implications. Mol Biol Evol 2002; 19(5):640-653. PMID: 11961098.

${ }^{10} \mathrm{Wu}$ XW, Muzny DM, Lee CC, Caskey CT. Two independent mutational events in the loss of urate oxidase during hominoid evolution. J Mol Evol 1992; 34(1):78-84. PMID: 1556746.
${ }^{11}$ Wu XW, Lee CC, Muzny DM, Caskey CT. Urate oxidase: Primary structure and evolutionary implications. Proc Natl Acad Sci U S A. 1989; 86(23):9412-9416. PMID: 2594778.

${ }^{12}$ Doherty M. New insights into the epidemiology of gout. Rheumatology (Oxford) 2009; 48(Suppl 2):ii2-ii8. PMID: 19447779.

13 Edwards NL. The role of hyperuricemia and gout in kidney and cardiovascular disease. Cleve Clin J Med 2008; 75(Suppl 5):Sl3-16. PMID; 18822470 .

${ }^{14}$ Simman R, Kirkland B, Jackson S. Posttraumatic tophaceous gout: A case report and literature review. J Am Col Certif Wound Spec 2009; 1(4):114116. PMID: 24527130.

${ }_{15}$ Fam AG. Gout, diet, and the insulin resistance syndrome. J Rheumatol 2002; 29(7):1350-1355. PMID: 12136887.

${ }^{16}$ Martin D, Joliat GR, Fournier P, Brunel C, Demartines N, Gie O. An unusual location of gouty panniculitis: A case report. Medicine (Baltimore) 2017; 96(16):e6733. PMID: 28422890.

17 Kumar P, Das A, Savant SS, Mandal RK, Hassan S. Gout nodulosis: Report of a rare case and brief review. Dermatol Online J 2015; 21(1):13030. PMID: 25612124.

18 Nakayama DA, Barthelemy C, Carrera G, Lightfoot RW Jr, Wortmann RL. Tophaceous gout: A clinical and radiographic assessment. Arthritis Rheum 1984; 27(4):468-471. PMID: 6712761.

19 Gutman AB. The past four decades of progress in the knowledge of gout, with an assessment of the present status. Arthritis Rheum 1973; 16(4):431445. PMID: 4147308

${ }^{20}$ Forbess LJ, Fields TR. The broad spectrum of urate crystal deposition: Unusual presentations of gouty tophi. Semin Arthritis Rheum 2012; 42(2):146-154. PMID: 22522111.

${ }^{21}$ Aradoini N, Talbi S, Berrada K, Abourazzak FZ, Harzy T. Chronic tophaceous gout with unusual large tophi: Case report. Pan Afr Med J 2015; 22:132. PMID: 26889313.

${ }^{22}$ Gaviria JL, Ortega VG, Gaona J, Motta A, Medina Barragan OJ. Unusual dermatological manifestations of gout: Review of literature and a case report. Plast Reconstr Surg Glob Open 2015; 3(7):e445. PMID: 26301134

${ }^{23}$ Rott KT, Agudelo CA. Gout. JAMA 2003; 289(21):2857-2860. PMID: 12783917.

24 TerkeltaubRA.Clinical practice. Gout.NEngl J Med2003;349(17):16471655. PMID: 14573737.

25 Dorsey ML, Roberts CC. Tophaceous gout mimicking an edematous anconeus epitrochlearis. Radiol Case Rep 2006; 1(4):140-144. PMID: 27298704

${ }^{26}$ Loeb JN. The influence of temperature on the solubility of monosodium urate. Arthritis Rheum 1972; 15(2):189-192. PMID: 5027604.

${ }^{27}$ Chowalloor PV, Siew TK, Keen HI. Imaging in gout: A review of the recent developments. Ther Adv Musculoskelet Dis 2014; 6(4):131-143. PMID: 25342993.

28 Neogi T. Clinical practice. Gout. N Engl J Med 2011; 364(5):443-452. PMID: 21288096

${ }^{29}$ Jordan KM, Cameron JS, Snaith M, et al. British Society for Rheumatology and British Health Professionals in Rheumatology guideline for the management of gout. Rheumatology (Oxford) 2007; 46(8):1372-1374. PMID: 17522099

${ }^{30}$ Harrold LR, Yood RA, Mikuls TR, et al. Sex differences in gout epidemiology: Evaluation and treatment. Ann Rheum Dis 2006; 65(10):1368-1372. PMID: 16644784.

31 Abbott KC, Kimmel PL, Dharnidharka V, Oglesby RJ, Agodoa LY, Caillard S. New-onset gout after kidney transplantation: Incidence, risk factors and implications. Transplantation 2005; 80(10):1383-1391. PMID: 16340779 .

32 Stamp L, Searle M, O’Donnell J, Chapman P. Gout in solid organ transplantation: A challenging clinical problem. Drugs 2005; 65(18):2593-2611. PMID: 16392875.

${ }^{33}$ Kumar R, Sahni VK, Jauhar S. Finger flexion contracture: First manifestation of gout. J Orthop Case Rep 2015; 5(2):66-68. PMID: 27299049.

34 Jalan D, Maley DK, Elhence A, Elhence P, Jain P. Massive gouty tophi presenting as pseudotumor of the elbow: A rare presentation. Cureus 2020; 12(1):e6769. PMID: 32140336.

${ }^{35}$ Lans J, Machol JA 4th, Deml C, Chen NC, Jupiter JB. Nonrheumatoid arthritis of the hand. J Hand Surg Am 2018; 43(1):61-67. PMID: 29132785.

36 Patel UJ, Freetly TJ, Yueh J, Campbell C, Kelly MA. Chronic tophaceous gout presenting as bilateral knee masses in an adult patient: A case report. $\mathrm{J}$ Orthop Case Rep 2019; 9(5):16-19. PMID: 32547995.

37 Ozturk R, Atalay IB, Bulut EK, Beltir G, Yilmaz S, Gungor BS. Place of orthopedic surgery in gout. Eur J Rheumatol 2019; 6(4):212-215. PMID: 31657704 . 
38 Ozturk R, Arikan SM, Bulut EK, Kekec AF, Celebi F, Gungor BS. Distribution and evaluation of bone and soft tissue tumors operated in a tertiary care center. Acta Orthop Traumatol Turc 2019; 53(3):189-194. PMID: 30982757.

39 Ochoa CD, Valderrama V, Mejia J, et al. Panniculitis: Another clinical expression of gout. Rheumatol Int 2011; 31(6):831-835. PMID: 20730459.

${ }^{40}$ Goebel L, Schneider G, Bohle R, Veith C, Orth P. Gouty tophus in the quadriceps tendon: Exclude malignancy. Lancet 2019; 394(10215):2197. PMID: 31839190

${ }^{41}$ Hopper G, Gupta S, Bethapudi S, Ritchie D, Macduff E, Mahendra A. Tophaceous gout of the patella: A report of two cases. Case Rep Rheumatol 2012; 2012:253693. PMID: 23198243.

${ }^{42}$ Ko KH, Hsu YC, Lee HS, Lee CH, Huang GS. Tophaceous gout of the knee: Revisiting MRI patterns in 30 patients. J Clin Rheumatol 2010; 16(5):209-214. PMID: 20661066.

${ }^{43}$ Chen CK, Yeh LR, Pan HB, et al. Intra-articular gouty tophi of the knee: CT and MR imaging in 12 patients. Skeletal Radiol 1999; 28(2):75-80. PMID: 10197451.

${ }^{44} \mathrm{Yu}$ KH, Lien LC, Ho HH. Limited knee joint range of motion due to invisible gouty tophi. Rheumatology (Oxford) 2004; 43(2):191-194. PMID: 12949254.

45 Recht MP, Seragini F, Kramer J, Dalinka MK, Hurtgen K, Resnick D. Isolated or dominant lesions of the patella in gout: A report of seven patients. Skeletal Radiol 1994; 23(2):113-116. PMID: 8191294.

46 Weaver J, Somani N, Bauer TW, Piliang M. Simple non-staining method to demonstrate urate crystals in formalin-fixed, paraffin-embedded skin biopsies. J Cutan Pathol 2009; 36(5):560-564. PMID: 19476524.

${ }^{47}$ Simkin PA, Bassett JE, Lee QP. Not water, but formalin, dissolves urate crystals in tophaceous tissue samples. J Rheumatol 1994; 21(12):23202321. PMID: 7699635.

Keywords: gout, gouty arthritis, tibia, elbow, surgical margins
KANSAS JOURNAL of MEDICINE SUBCUTANEOUS GOUTY TOPHI

continued. 